\title{
PENGARUH KOMISARIS INDEPENDEN, KOMITE AUDIT, DAN FINANCIAL DISTRESS TERHADAP INTEGRITAS LAPORAN KEUANGAN
}

\author{
Anita Indrasari, Willy Sri Yuliandhari dan Dedik Nur Triyanto \\ Fakultas Ekonomi Universitas Telkom \\ Email: ksyinnercircle@gmail.com
}

\begin{abstract}
The purpose of this reseach is to examine the influence of independent commissioner, audit committee, and financial distress to integrity of financial statement of property and real estate companies listed in Indonesia Stock Exchange either partially or simultaneously for the years 2005-2014. This research was performed using panel data regression with the help of a computer program Eviews version 8.0. The results of partially for the year 2005-2014, that only independent commissioner which has influence on the integrity of financial statements, while audit committee and financial distress has no effect on integrity of financial statements. While simultaneously independent commissioner, audit committee, and financial distress jointly have a significant impact on integrity of financial statements. Recommendation for next studies to added new independent variables that predicted influence to integrity of financial statements, such as independency and quality auditors and good corporate governance mechanism.
\end{abstract}

Key words: independent commissioner, audit committee, financial distress, integrity of financial statements.

Abstak: Tujuan penelitain ini adalah untuk membahas tentang pengaruh komisaris independen, komite audit dan financial distress terhadap integritas laporan keuangan pada perusahaan property dan real estate yang terdaftar di Bursa Efek Indonesia baik secara parsial maupun simultan pada tahun 2005-2014. Penelitian ini dilakukan dengan menggunakan regresi data panel dengan bantuan program komputer Eviews versi 8.0. hasil penelitian secara parsial pada tahun 2005-2014 menunjukkan bahwa hanya komisaris independen yang memiliki pengaruh terhadap integritas laporan keuangan, sementara komite audit dan financial distress tidak berpengaruh terhadap integritas laporan keuangan. Sedangkan secara simultan, variabel komisaris independen, komite audit dan financial distress secara bersama-sama mempunyai pengaruh terhadap integritas laporan keuangan. Disarankan untuk penelitian berikutnya untuk menambah variabel independen baru yang diprediksi dapat berpengaruh terhadap integritas laporan keuangan seperti independensi dan kualitas auditor dan mekanisme good corporate governance.

Kata Kunci: komisaris independen, komite audit dan financial distress, integritas laporan keuangan.

\section{PENDAHULUAN}

Penyajian laporan keuangan yang wajar mensyaratkan penyajian secara jujur dampak dari transaksi, peristiwa dan kondisi lain dalam suatu entitas. Dengan demikian, laporan keuangan harus menyajikan informasi yang berintegritas tinggi (PSAK no. 1, 2014). Integritas laporan keuangan adalah laporan keuangan yang menampilkan kondisi suatu 
perusahaan yang sebenarnya, tanpa ada yang ditutupi atau disembunyikan (Hardiningsih, 2010). Namun, pada kenyataannya mewujudkan integritas laporan keuangan merupakan hal yang berat. Terbukti terjadi beberapa kasus yang membuat keraguan terhadap tingkat integritas laporan keuangan.

Kasus yang terjadi pada tahun 2009 menimpa perusahaan BUMN yaitu Waskita Karya yang melakukan kelebihan pencatatan laba bersih pada laporan keuangan 20042008 sekitar Rp 400 miliar. Laba yang seharusnya masuk pembukuan tahun depan dicatat sebagai laba tahun lalu. Terbongkarnya kasus ini bermula saat pemeriksaan kembali neraca dalam rangka penerbitan saham perdana. Direktur menemukan penctatan yang tidak sesuai. Selain itu pada tahun 2013 PT Bakrieland Development Tbk (ELTY) tidak mengungkapkan kewajiban jangka panjang yang sebenarnya. Perusahaan memiliki hutang obligasi sebesar US\$ 155 juta dan tidak dapat membayarnya saat jatuh tempo. Akhirnya Otoritas Jasa Keuangan (OJK) mendesak agar perusahaan segera memberikan laporan terbuka kepada publik, karena sebagai perusahaan terbuka seharusnya mengungkapkan semua informasi yang terkait dengan perusahaan.

Dari fenomena diatas dapat dilihat bahwa PT Waskita Karya dan PT Bakrieland Development menimbulkan ketidakpercayaan dari pengguna laporan keuangan dan mempertanyakan integritas laporan keuangan yang disajikan. PT Waskita Karya tidak menyajikan laba perusahaan yang sebenarnya dan PT Bakrieland Development tidak secara terbuka mengungkapkan kejadian yang ada di dalam perusahaan. Integritas laporan keuangan adalah laporan keuangan yang menampilkan kondisi suatu perusahaan yang sebenarnya, tanpa ada yang ditutup-tutupi atau disembunyikan (Hardiningsih, 2010).

Selain itu, pada kasus yang terjadi pada PT Waskita Karya terdapat kelebihan pencatatan (overstate) laba pada tahun 2004-2008. Kasus ini diketahui setelah adanya pergantian direksi dan pemeriksaan kembali neraca terkait dengan penawaran saham perdana yang akan dilakukan oleh perusahaan. Dari fenomena tersebut, masih perlu dipertanyakan mengenai pengawasan terhadap pelaporan keuangannya. Agar dapat tercapai laporan keuangan yang berintegritas diperlukan adanya pengawasan, biasanya dilakukan oleh Komisaris Independen dan Komite Audit. Salah satu fungsi Komisaris Independen adalah melakukan pengawasan secara umum dan/atau khusus sesuai dengan anggaran dasar dan memberi saran kepada Direksi (Peraturan Otoritas Jasa Keuangan No. 33/POJK.04/2014 tentang Direksi dan Dewan Komisaris Emiten atau Perusahaan Publik). Kemudian salah satu fungsi dari Komite Audit adalah untuk melakukan penelaahan atas informasi keuangan yang akan dikeluarkan kepada publik serta memberikan rekomendasi kepada Dewan Komisaris dalam penunjukan akuntan publik yang didasarkan pada indepndensi, ruang lingkup penugasan dan fee (Keputusan Ketua Bapepam-LK No. KEP643/BL/2012 tentang Pembentukan dan Pedoman Pelaksanaan Kerja Komite Audit).

Berdasarkan dengan peraturan diatas, seharusnya peran Komisaris Independen dan Komite Audit dapat dimaksimalkan dalam melakukan pengawasan. Pada tahun 2009 diketahui bahwa jumlah Komisaris Independen sudah memenuhi persyaratan dari OJK yaitu 30\% dari jumlah seluruh Dewan Komisaris dan jumlah Komite Audit sebanyak 3 orang. Anggota Komisaris Independen ini sudah menjabat sejak tahun 2007 dan Komite Audit menjabat sejak tahun 2004. Namun, kelebihan pencatatan (overstate) yang terjadi sejak tahun 2004-2008 tidak dapat terungkap.

Berdasarkan dengan penelitian sebelumnya, terdapat inkonsistensi penelitaian pada beberapa variabel, sehingga penelitian ini masih relevan untuk diteliti kembali. Dalam 
penelitian ini variable yang akan diteliti adalah komisaris independen, komite audit dan financial distress untuk mengetahui pengaruhnya terhadap integritas laporan keuangan.

\section{KAJIAN TEORI}

Komisaris Independen. Menurut Peraturan Otoritas Jasa Keuangan No. 33/POJK.04/2014 tentang Direksi dan Dewan Komisaris Emiten atau Perusahaan Publik, Dewan Komisaris bertugas melakukan pengawasan dan bertanggung jawab atas pengawasan terhadap kebijakan pengurusan, jalannya pengurusan pada umumnya, baik mengenai Emiten atau Perusahaan Publik maupun usaha Emiten atau Perusahaan Publik, dan memberi nasihat kepada Direksi. Dewan Komisaris paling kurang terdiri dari 2 (dua) orang anggota dan 1 (satu) diantaranya adalah Komisaris Independen. Jumlah Komisaris Independen wajib paling kurang 30\% dari jumlah seluruh anggota Dewan Komisaris. (www.ojk.go.id). Dalam penelitian ini untuk menghitung jumlah komisaris independen adalah dengan membagi jumlah komisaris independen dengan jumlah dewan komisaris.

\section{$\mathrm{KI}=\frac{\text { Jumlah Komisaris Independen }}{\text { Jumlah Dewan Komisaris }} \times \mathbf{1 0 0} \%$}

Komite Audit. Komite audit adalah komite yang dibentuk oleh dan bertanggungjawab kepada Dewan Komisaris dalam membantu melaksanakan tugas dan fungsi Dewan KomisarisKomite audit diketuai oleh seorang Komisaris Independen. Komite audit paling kurang terdiri dari 3 (tiga) orang anggota yang berasal dari Komisaris Independen dan pihak luar Emiten atau Perusahaan Publik (Keputusan Ketua Bapepem-LK No. KEP643/BL/2012). Oleh karena itu, dalam penelitian ini, variabel komite audit diukur dengan menghitung berapa jumlah komite audit dalam sebuah perusahaan setiap tahunnya

Financial Distress. Perusahaan yang mengalami financial distress merupakan perusahaan yang mengalami gejala-gejala awal terhadap penurunan kondisi laporan keuangan (Risdiyani dan Kusmuriyanto, 2015).Financial distress dimulai ketika perusahaan tidak dapat memenuhi jadwal pembayaran atau ketika proyeksi arus kas mengindikasikan bahwa perusahaan tersebut akan segera tidak dapat memenuhi kewajibannya (Nugroho, 2012). Hal ini dapat juga disebut sebagai insolvensiyang wajar, kemungkinan hanya sementara dan dapat diperbaiki. Jadi, insolvensi yang wajar hanya menujukkan kurangnya likuiditas. Perbaikan bagi perusahaan yang gagal bermacam-macam dalam hal kekerasannya menurut tingkat kesulitan keuangan. Jika keliahatannya cukup berat, likuiditas mungkin satu-satunya alternatif yang layak. Akan tetapi, beberapa perusahaan yang gagal dapat direhabilitasi agar dapat menguntungkan kreditor, pemegang saham, dan masyarakat (Horne \& Wachowicz, 2012:516). Dalam penelitian ini, pengukuran financial distress diukur dengan metode Z-Score dengan empat jenis rasio keuangan yang dikemukakan oleh Altman. Fungsi diskriminan Z-Score yang ditentukan oleh Altman untuk perusahaan nonmanufaktur menggunakan rumus sebagai berikut:

Keterangan:

$$
\mathrm{Z}=6,56 \mathrm{X} 1+3,26 \mathrm{X} 2+6,72 \mathrm{X} 3+1,05 \mathrm{X} 4
$$

$\mathrm{Z}$ : bankrupty index; X1 : working capital (aset lancar - kewajiban lancar) / total aset; X2 : retained earning / total asset; X3 : EBIT / total asset; X4 : market value of equity / total liabilities 
Menurut Altman (2006:248), terdapat angka-angka untuk kategori zona diskriminasi nilai $\mathrm{Z}$ yang dapat menjelaskan apakah perusahaan akan mengalami kegagalan atau tidak pada masa mendatang dan Altman membaginya ke dalam tiga kategori, yaitu zona aman jika $Z>2,60$, zona abu-abu jika nilai $Z$ antara 1,1 - 2,60, sedangkan yang masuk ke dalam zona distress atau bangkrut adalah $\mathrm{Z}<1,1$.

Integritas Laporan Keuangan. Laporan keuangan yang berintegritas harus memenuhi dua karakteristik utama laporan keuangan yaitu relevan dan keandalan. Informasi keuangan yang memiliki integritas yang tinggi akan dapat diandalkan karena merupakan suatu penyajian yang jujur sehingga memungkinkan pengguna informasi bergantung pada informasi tersebut. Dalam penelitian ini, integritas laporan keuangan diproksikan dengan konservatisme. Konservatisme adalah sikap atau aliran dalam menghadapi ketidakpastian untuk mengambil tindakan atau keputusan atas dasar munculan yang terjelek dari ketidakpastian tersebut (Suwardjono, 2010:245). Prinsip konservatisme seringkali melakukan penundaan pengakuan kabar baik (good news) pada laporan keuangan, namun secepatnya mengakui kabar baik (bad news) (Subramanyam dan Wild, 2010:91). Dalam penelitian ini, pengukuran konservatisme berdasarkan metode Givoly dan Hayn (2000).

$$
\mathrm{CON}_{\downarrow} \mathrm{ACC}=\mathrm{NI}_{\mathrm{it}}-\mathrm{CFO}_{\text {it }}
$$

Keterangan: CON_ACC : Tingkat konservatisme akuntansi; $\mathrm{NI}_{\mathrm{it}}$ : Laba sebelum extraordinary items + depresiasi dari perusahaan i pada tahun $\mathrm{t} ; \mathbf{C F o}_{\mathrm{it}}$ : Arus kas dari kegiatan operasi perusahaan i pada tahun t.

Apabila laba yang dihasilkan lebih rendah daripada arus kas operasi, maka ada indikasi penerapan prinsip konservatisme. Ada kecenderungan dari akun akrual selama beberapa tahun. Apabila terjadi akrual negatif (net income lebih kecil daripada cash flow operasional) yang konsisten selama beberapa tahunatau nilai CON_ACC kurang dari 0, maka ada indikasi diterapkannya konservatisme. Sementara itu, penggunaan laba sebelum extraordinary items bertujuan untuk menghilangkan elemen yang menyebabkan pertumbuhan laba meningkat dalam satu periode tertentu yang tidak akan timbul dalam periode lainnya (Givoly dan Hayn, 2000).

Pengaruh Komisaris Indepeneden terhadap Integritas Laporan Keuangan. Dengan fungsi komisaris independen sebagai pengawas kinerja manajemen secara luas dan menyeluruh, maka tingkat pengungkapan informasi yang lebih andal dan tidak memihak dapat diharapkan dari perusahaan dengan proporsi komisaris independen yang lebih tinggi (Saksakotama, 2014). Pernyataan ini didukung dengan penelitian yang mengatakan bahwa keberadaan komisaris indepeden pada suatu perusahaan dapat mempengaruhi integritas suatu laporan keuangan yang dihasilkan oleh manajemen, karena di dalam perusahaan terdapat badan yang mengawasi secara langsung dan melindungi hak pihak-pihak minoritas diluar manajemen perusahaan. (Hardiningsih, 2010).

Pengaruh Komite Audit terhadap Integritas Laporan Keuangan. Komite audit dari dewan komisaris memiliki peran penting dalam mengawasi dan menonitor audit laporan keuangan, memastikan agar standar dan kebijakan keuangan yang berlaku telah terpenuhi, menelaah laporan keuangan serta hasil audit internal dan eksternal, mengawasi pengendalian internal perusahaan dan mengkomunikasikan hal-hal yang berhubungan dengan audit kepada dewan komisaris. Keberadaan komite audit bermanfaat untuk 
menjamin transparansi, keterbukaan laporan keuangan, keadilan untuk semua pemegang saham dan pengungkapan semua informasi yang dialkukan oleh manajemen. Dengan demikian komite audit dalam perusahaan dapat menjadi salah satu upaya dalam mengurangi menipulasi dalam penyajian informasi akuntansi sehingga keintegritasan laporan keuangan dapat meningkat (Nicolin dan Sabeni, 2013).

Pengaruh Financial Distress terhadap Integritas Laporan Keuangan. Teori akuntansi positif menyebutkan bahwa manajer akan cenderung mengurangi tingkat konservatisme akuntansi apabila perusahaan mengalami tingkat kesulitan keuangan (financial distress) yang tinggi karena apabila terjadi financial distress mengindikasikan kinerja buruk manajemen dan akan mengakibatkan pergantian manajemen. Oleh karena itu manajer akan mengurangi tingkat konservatisme (Noviantari dan Ratnadi, 2015). Konservatisme akuntansi mengindikasikan adanya integritas laporan keuangan karena untuk menghindari manipulasi dan meningkatkan integritas, praktik akuntansi konservatif dibutuhkan (Smith dkk, 2011). Pernyataan ini didukung dengan penelitian-penelitian terdahulu yang telah dilakukan oleh beberapa peneliti. Seperti pada penelitian yang dilakukan oleh Dewi dan Suryanawa (2014), Fathurahmi dkk (2015), dan Noviantari dan Ratnadi (2015) yang menyatakan bahwa financial distress memiliki pengaruh negatif terhadap konservatisme akuntansi.

Berikut merupakan pemaparan gambar kerangka pemikiran dalam penelitian ini:

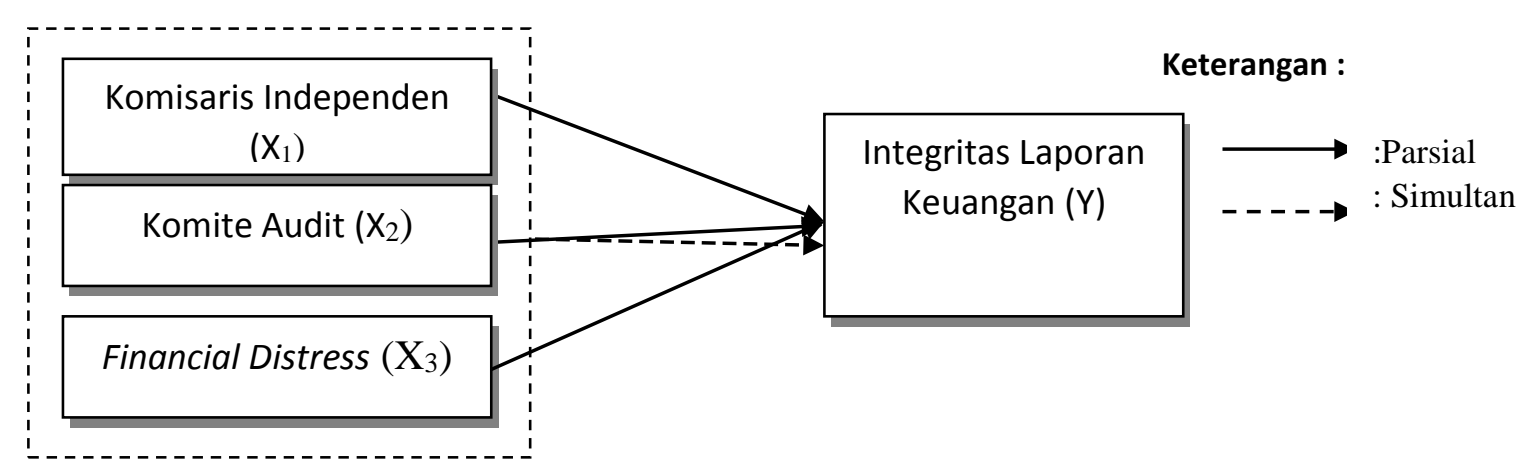

Gambar 1. Kerangka Pemikiran

Hipotesis Penelitian. Berdasarkan teori dan kerangka pemikiran yang telah dijelaskan pada bagian sebelumnya, maka peneliti memiliki hipotesis sebagai berikut: (1) Terdapat pengaruh simultan antara komisaris independen, komite audit dan financial distress terhadap integritas laporan keuangan pada perusahaan sektor property dan real estate yang terdaftar di Bursa Efek Indonesia tahun 2010-2014; (2) Terdapat pengaruh positif secara parsial antara komisaris independen terhadap integritas laporan keuangan pada perusahaan sektor property dan real estate yang terdaftar di Bursa Efek Indonesia tahun 2010-2014; (3) Terdapat pengaruh positif secara parsial antara komite audit terhadap integritas laporan keuangan pada perusahaan sektor property dan real estate yang terdaftar di Bursa Efek Indonesia tahun 2010-2014; (4) Terdapat pengaruh negatif secara parsial antara financial distress terhadap integritas laporan keuangan pada perusahaan sektor property dan real estate yang terdaftar di Bursa Efek Indonesia tahun 2010-2014. 


\section{METODE}

Populasi yang digunakan dalam penelitian ini adalah perusahaan sektor property dan real estate yang terdaftar di Bursa Efek Indonesia (BEI) periode tahun 2010-2014. Metode pengambilan sampel adalah purposive sampling, yaitu teknik penentuan sampel dengan pertimbangan tertentu (Sugiyono, 2013:68). Adapun kriteria dalam pengambilan sampel adalah sebagai berikut: (1) Perusahaan sektor property dan real estate yang terdaftar di Bursa Efek Indonesia pada tahun 2005 - 2014; (2) Perusahaan sektor property dan real estate yang konsisten menerbitkan laporan tahunan pada tahun 2005 - 2014 di Bursa Efek Indonesia; (3) Perusahaan sektor property dan real estateyang data-datanya tidak lengkap pada tahun 2005 - 2014.

Dari kriteria pemilihan sampel diatas, yang menjadi sampel perusahaan berjumlah 17 (tujuh belas) perusahaan. Dalam penelitian ini menggunakan data kuantitatif yang menggunakan data sekunder. Dalam memperoleh data tersebut dapat menggunakan metode: (a) Studi Pustaka; dilakukan dengan memperoleh, mempelajari dan membaca jurnal, literatur, buku, artikel, serta referensi lainnya untuk memperoleh pemahaman mengenai komisaris independen, komite audit, indepedensi, kualitas auditor dan integritas laporan keuangan. (b) Dokumentasi; dengan melihat dokumen yang sudah tersedia, sember data dalam penelitian ini adalah laporan keuangan perusahaan sektor property dan real estate yang terdaftar di BEI pada tahun 2005-2014, yang diambil dari www.idx.co.id.

Metode Analisis Data. Model analisis data yang digunakan dalam penelitian ini adalah dengan menggunakan analisis rgresi data panel. Model umum regresi data panel (dalam notasi matriks) adalah sebagai berikut:

$$
\text { Yit }=\alpha+\text { Xit } \beta+\text { uit }
$$

Keterangan: i : $1,2, \ldots$, menunjukkan rumah tangga, indivisu, perusahaan, dan lainnya (dimensi data silang); $\mathrm{t}: 1,2, \ldots, \mathrm{t}$, menunjukkan dimensi deret waktu; $\alpha$ : Koefisien intersep yang merupakan scalar; $\beta$ : koefisien slope dengan dimensi $\mathrm{K} \times 1$, dimana $\mathrm{K}$ adalah banyaknya perubahan waktu; Yit : perubahan tak bebas untuk unit individu ke-I dan unit waktu ke-t; Xit : perubahan bebas untuk unit individu ke-I dan unit waktu ke-t; uit : faktor gangguan (disturbance).

Tahapan Analisis Data. Analisis Statistik Deskriptif. Statistik deskriptif adalah statistik yang digunakan untuk menganalisis data dengan cara mendeskripsikan atau menggambarkan data yang telah terkumpul sebagaimana adanya, tanpa bermaksud membuat kesimpulan yang berlaku umum atau generalisasi. Statistik deskriptif meliputi penyajian data melalui tabel, grafik, diagram lingkaran, pictogram, perhitungan modus, median, mean (pengukuran tendensi sentral), perhitungan desil, persentil, perhitungan penyebaran data melalui perhitungan perhitungan rata-rata dan standar deviasi ataupun perhitungan persentase (Sugiyono, 2013:200). Statistik deskriptif menjelaskan nilai ratarata (mean) dari data, standar deviasi yang digunakan untuk mengetahui seberapa besar data yang berkaitan bervariasi dengan rata-rata, kemudian nilai minimum, yaitu nilai terkecil dari data yang diteliti dan maksimum, yaitu nilai terbesar dari data yang diteliti.

Analisis Regresi Data Panel. Regresi data panel dalam penelitian ini dihitung dengan menggunakan bantuan program komputer yaitu Eviews versi 8.0. Menurut Rosadi 
(2012:274) terdapat tiga macam uji yang dapat dilakukan yaitu Uji Chow (likelihood test), Uji Haussman, serta uji Lagrance Multipier.

1. Uji Chow. Pengujian ini untuk menentukan apakah model common effect atau fixed effect yang akan digunakan. Kriteria dengan pengujian ini adalah dengan hipotesis:

$\mathrm{H}_{0}=$ Model common effect

$\mathrm{H}_{1}=$ Model fixed effect

Dengan kriteria pengambilan keputusan $(\alpha=0,05)$ : (a) Jika nilai probability crosssection chi-square $\leq 0.05$ maka $\mathrm{H}_{0}$ ditolak, sehingga akan menggunakan model fixed effect; (b) Jika nilai probability cross-section chi-square $>0.05$ maka $\mathrm{H}_{0}$ diterima sehingga yang digunakan adalah model common effect.

2. Uji Hausman. Hausman telah mengembangkan suatu uji untuk memilih apakah metode Fixed Effect dan metode Random Effect lebih baik dari metode CommonEffect. Uji Hausman ini didasarkan pada ide bahwa Least Squares Dummy Variables (LSDV) dalam metode metode Fixed Effect dan Generalized Least Squares (GLS) dalam metode Random Effect adalah efisien sedangkan Ordinary Least Squares (OLS) dalam metode Common Effect tidak efisien. Dilain pihak, alternatifnya adalah metode OLS efisien dan GLS tidak efisien. Karena itu, uji hipotesis nulnya adalah hasil estimasi keduanya tidak berbeda sehingga uji Hausman bisa dilakukan berdasarkan perbedaan estimasi tersebut. Kriteria dar pengujian ini adalah sebagai berikut:

$\mathrm{H}_{0}=$ Model Random effect

$\mathrm{H}_{1}=$ Model Fixed effect

a. Jika nilai probability Cross-section Random $\leq 0.05$ maka $\mathrm{H}_{0}$ ditolak, sehingga akan menggunakan model fixed effect.

b. Jika nilai probability Cross-section Random> 0.05 maka $\mathrm{H}_{0}$ diterima sehingga yang digunakan adalah model random effect.

3. Uji Lagrange Mutliplier (LM)

Uji ini dilakukan untuk mengetahui apakah model Random Effect lebih baik dari model Common Effect digunakan Lagrange Multiplier (LM). Uji Signifikansi Random Effect ini dikembangkan oleh Breusch-Pagan. Pengujian didasarkan pada nilai residual dari metode Common Effect. Dengan kriteria dari pengujian ini adalah dengan hipotesis:

$\mathrm{H}_{0}=$ Model Common effect (PLS)

$\mathrm{H}_{1}=$ Model Random effect (RE)

Persamaannya adalah:

$\mathrm{LM}=\frac{\mathrm{nT}}{2(\mathrm{~T}-1)}\left[\frac{\sum_{\mathrm{i}=1}^{\mathrm{n}}\left[\sum_{\mathrm{t}=1}^{\mathrm{T}} \mathrm{e}_{\mathrm{it}}\right]^{2}}{\sum_{\mathrm{i}=1}^{\mathrm{n}}\left[\sum_{\mathrm{t}=1}^{\mathrm{T}} \mathrm{e}_{\mathrm{it}}\right]^{2}}-1\right]^{2}$

Dimana $\mathrm{n}$ adalah jumlah individu; $\mathrm{T}$ adalah jumlah periode waktu, dan eit adalah residual metode PLS. Uji LM ini didasarkan pada distribusi chi-square dengan derajat bebas sebesar 1. Jika hasil statistik LM lebih besar dari nilai kritis statistik chi-square, maka hipotesis nol akan ditolak, yang berarti estimasi yang tepat untuk regresi data panel adalah metode REM. Penggunaan metode ini jarang dilakukan karena apabila model yang terpilih random effect karena di dalam random effect model terdapat Generalized Least Square dan Weighted Least Square dimana tidak diperlukannya lagi uji asumsi dalam regresi linear. 
Pengujian Hipotesis. Untuk melakukan pengujian terhadap hipotesis-hipotesis yang diajukan, perlu digunakan analisa regresi melalui uji F maupun uji t. Tujuan digunakan analisa regresi adalah untuk mengetahui pengaruh variabel-variabel independen terhadap variabel dependen, baik secara parsial maupun secara simultan, serta mengetahui besarnya dominasi variabel-variabel independen. Metode pengujian terhadap hipotesa yang diajukan, dilakukan dengan pengujian secara simultan dan pengujian secara parsial.

Uji Statistik F. Menurut Ghozali (2012:98), pengujian terhadap komisaris independen, komite audit, financial distress dan integritas laporan keuangan secara bersamaan (simultan) dilakukan dengan uji F. Uji statistik F pada dasarnya menunjukkan apakah semua variabel independen atau bebas yang dimasukkan dalam model mempunyai pengaruh secara bersama-sama terhadap variabel dependen/terikat. Adapun hipotesis yang hendak diuji dalam penelitian ini dirumuskan sebagai berikut: Pertama. Pengujian Hipotesis, dimana: (1) H0 : b $=0$. Tidak ada pengaruh yang signifikan antara variabel independen secara bersama-sama dengan variabel dependen; (2) HA : b $\neq 0$. Ada pengaruh yang signifikan antara variabel independen secara bersama-sama dengan variabel dependen. Kedua. Kriteria Pengujujian. (1) Bila F hitung .nilai F table, maka H0 ditolak dan menerima HA. Hal ini berarti bahwa terdapat hubungan yang signifikan antara variabel komisaris independen (variabel $X_{\mathbf{1}}$ ), komite audit (variabel $X_{\mathbf{2}}$ ), financial distress (variabel $X_{\mathbf{z}}$ ), dengan integritas laporan keuangan (variabel $\mathrm{Y}$ ). (2) Bila F hitung < nilai $\mathrm{F}$ table, maka H0 diterima dan HA ditolak. Jal ini berarti bahwa tidak terdapat hubungan yang signifikan antara variabel komisaris independen (variabel $X_{1}$ ), komite audit (variabel $X_{\mathbf{z}}$ ), financial distress (variabel $X_{\mathbf{a}}$ ), dengan integritas laporan keuangan (variabel $Y$ ). Ketiga. Rumus Hipotesis secara simultan dalam penelitian ini: (1) $\mathbf{H O}_{1}: b_{1}=b_{\mathbf{2}}=0$. Komisaris independen, komite audit, dan financial distress secara simultan tidak memiliki pengaruh signifikan terhadap integritas laporan keuangan. (2) $\mathbf{H A}_{\mathbf{1}}: b_{\mathbf{1}}=b_{\mathbf{2}} \neq 0$. Komisaris independen, komite audit, dan financial distresssecara simultan memiliki pengaruh signifikan terhadap integritas laporan keuangan.

Uji Statistik t. Menurut Ghozali (2012:98), pengujian hipotesis untuk masing-masing variabel independen, yaitu Komisaris independen, komite audit, financial distress dan integritas laporan keuanganmenggunakan uji regresi parsial (uji t). Uji statistik t pada dasarnya menunjukkan seberapa jauh pengaruh satu variabel independen secara individual dalam menerangkan variasi variabel dependen. Pertama. Pengujian Hipotesis: (1) H0 : b $=0$. Tidak ada pengaruh yang signifikan antara variabel independen secara indivisu (parsial) dengan variabel dependen. (2) HA : b $\neq 0$. Ada pengaruh yang signifikan antara variabel independen secara indivisu (parsial) dengan variabel dependen. Kedua. Kriteria Pengujian, (1) t hitung > t tabel, maka kita menerima hipotesis alternatif, yaitu variabel $X$ secara individu (parsial) memiliki pengaruh yang signifikan terhadap variabel Y. (2) t hitung $<\mathrm{t}$ tabel, maka kita menerima hipotesis nol, yaitu variabel $\mathrm{X}$ secara indivisu (parsial) tidak memiliki pengaruh signifikan terhadap variabel Y. Ketiga. Rumus hipotesis secara parsial dalam penelitian ini: (1) $\mathrm{HO}_{2}$ : Komisaris independen secara parsial tidak memiliki pengaruh signifikan terhadap integritas laporan keuangan. (2) $\mathbf{H A}_{\mathbf{2}}$ : Komisaris independen secara parsial memiliki pengaruh signifikan terhadap integritas laporan keuangan. (3) $\mathrm{HO}_{3}$ : Komite audit secara parsial tidak memiliki pengaruh signifikan terhadap integritas laporan keuangan. (4) $\mathbf{H A}_{3}$ : Komite audit secara parsial memiliki 
pengaruh signifikan terhadap integritas laporan keuangan. (5) $\mathbf{H 0}_{4}$ : Financial distress secara parsial tidak memiliki pengaruh signifikan terhadap integritas laporan keuangan. (6) $\mathbf{H A}_{4}$ : Financial distress secara parsial memiliki pengaruh signifikan terhadap integritas laporan keuangan.

Koefisien Determinasi $\left(\boldsymbol{R}^{\mathbf{2}}\right)$. Menurut Ghozali (2012:97), koefisien determinasi $\left(R^{\mathbf{2}}\right)$ pada intinya mengukur seberapa jauh kemampuan model dalam menerangkan variasi variabel independen. Nilai koefisien determinasi adalah antara nol dan satu. Nilai $R^{\mathbf{z}}$ yang kecil berarti kemampuan variabel-variabel independen dalam menjelaskan variasi variabel dependen amat terbatas. Nilai yang mendekati satu berarti variabel-variabel independen hampir memberikan semua informasi yang dibutuhkan untuk memprediksi variasi variabel dependen. Dengan kata lain, semakin tinggi nilai koefesien determinasi berarti semakin baik kemampuan variabel independen dalam menjelaskan perilaku variabel dependen.

\section{HASIL DAN PEMBAHASAN}

Analisis Statistik Deskriptif. Berikut adalah hasil statistik deskriptif setiap variabel operasional:

Tabel 1. Hasil Uji Statistik Deskriptif

\begin{tabular}{ccccc}
\hline & $\begin{array}{c}\text { Komisaris } \\
\text { Independen }\end{array}$ & Komite Audit & $\begin{array}{c}\text { Financial } \\
\text { Distress }\end{array}$ & $\begin{array}{c}\text { Integritas } \\
\text { Laporan } \\
\text { Keuangan }\end{array}$ \\
\hline Mean & 0.447776 & 3.005882 & 2.616393 & 442.1974 \\
Maximum & 0.750000 & 4.000000 & 27.99600 & 5313.775 \\
Minimum & 0.250000 & 3.000000 & -38.38000 & -1337.088 \\
Std. Dev. & 0.100989 & 0.076696 & 6.672056 & 791.5006 \\
\hline
\end{tabular}

Hasil dari uji deskriptif dalam penelitian ini menjelaskan secara deskriptif masing-masing variabel yang digunakan. Dari data tersebut menunjukkan bahwa ada variabel operasional yang memiliki nilai rata-ratayang lebih besar dari standar deviasi dan ada variabel operasional yang memiliki nilai rata-ratayang lebih kecil dari standar deviasi. Hal ini menunjukkan bahwa data variabel operasional tersebut adalah menyebar atau bervariasi.

Berdasarkan analisis ststistik deskriptif dapat diketahui bahwa variabel komisaris independen memiliki nilai maksimum sebesar 0.75 dan nilai minimum sebesar 0.25 serta memiliki rata-rata sebesar 0.447776 dan standar deviasi sebesar 0.100989 . dari data tersebut dapat dilihat nilai rata-rata lebih besar jika dibandingkan dengan standar deviasi, ini menunjukkan bahwa komisaris independen pada perusahaan sektor Property dan Real Estate memiliki data yang tidak bervariasi. Pada penelitian ini, variabel komisaris independen dihitung dengan membandingkan jumlah komisaris independen dengan jumlah seluruh dewan komisaris yang ada dalam struktur perusahaan. Data variabel komisaris independen pada beberapa perusahaan setiap tahunnya berfluktuasi, hal ini dapat disebabkan oleh adanya pergantian dari anggota komisaris independen dan dewan komisaris independen. Pada beberapa perusahaan, tidak hanya anggotanya yang diganti, tapi dapat juga merubah jumlah anggota komisaris independen atau jumlah dewan komisaris yang ada dalam perusahaan tersebut. Perubahan struktur komisaris independen atau dewan komisaris dapat diakibatkan oleh berakhirnya masa jabatan sebagai dewan 
komisaris dan komisaris independen, anggota tersebut mengundurkan diri atau anggota tersebut meninggal dunia.

Data variabel komite audit memperlihatkan nilai maksimum sebesar 4 dan nilai minimum sebesar 3 serta rata-rata 3.005882 dan standar deviasi sebesar 0.076696. Hal ini menunjukkan data variabel komite audit tidak bervariasi karena rata-rata lebih besar dari nilai standar deviasi. Berdasarkan peraturan dari Bapepam-LK No. KEP-643/BL/2012 yang mengharuskan perusahaan memiliki susunan komite audit sebanyak minimal 3 orang yang diketuai oleh seorang komisaris independen dan anggotanya berasal dari pihak luar perusahaan. Data pada variabel komite audit menunjukkan nilai yang hampir semua sama. Dari 17 sampel perusahaan yang digunakan, semua sudah menerapkan peraturan yang dibuat oleh Bapepam-LK tersebut, yaitu memiliki komite audit sebanyak minimal 3 orang yang diketuai oleh seorang komisaris independen.

Data variabel financial distress memiliki nilai maksimum sebesar 27.99600 dan nilai minimum sebesar -38.38000, sedangkan nilai rata-rata sebesar 2.616393 dan standar deviasi sebesar 6.672056. Hal ini dapat dilihat bahwa nilai rata-rata lebih kecil daripada nilai standar deviasi, artinya data variabel financial distress adalah menyebar atau bervariasi. Nilai financial distress pada setiap perusahaan mengalami fluktuasi di setiap tahunnya. Hal ini biasanya disebabkan oleh nilai X1 (working capital / total asset) yang bernilai rendah atau negatif dan nilai X4 (market value of equity/ total liabilities) yang bernilai tinggi. X1 bernilai rendah atau negatif diakibatkan oleh kewajiban lancar yang lebih besar jika dibandingkan dengan aset lancarnya, sehingga saat dibagi dengan total aset akan bernilai negatif. Kewajiban lancar lebih besar daripada aset lancar biasanya disebabkan tingginya jumlah hutang kepada pihak ketiga. Selanjutnya untuk rasio X4 yang tinggi, biasanya disebabkan oleh tingginya harga saham pada suatu perusahaan. Harga saham tinggi dapat disebabkan oleh berbagai penyebab, diantaranya adanya kenaikan pendapatan yang diiringi oleh kenaikan laba bersih yang menyebabkan investor menjadi lebih tertarik untuk berinvestasi. Selain itu dapat pula diakibatkan oleh keadaan perusahaan yang dapat mengatasi kepailitannya dan bangkit kembali. Selain itu, dapat pula dari faktor perekonomian makro Indonesia yang sedang membaik dan kebangkitan perusahaan property dan real estate di Indonesia yang diiringi dengan penurunan suku bungan serta menurunnya tingkat inflasi. Perusahaan property dan real estate di Indonesia menjadi semakin menarik karena konsumsi terhadap gedung perkantoran, pusat perbelanjaan serta perumahan yang tinggi.

Selanjutnya variabel integritas laporan keuangan memiliki nilai maksimum sebesar 5313775 dan nilai minimum sebesar -1337088. Nilai rata-rata sebesar 442197.4 lebih kecil daripada nilai standar deviasi yaitu sebesar 791500.6. Hal ini menunjukkan bahwa data variabel integritas laporan keuangan menyebar atau bervariasi. Dari data deskriptif, terdapat beberapa perusahaan yang memiliki nilai integritas laporan keuangan yang positif selama tahun penelitian yaitu 2005-2014. Penyebabnya adalah nilai laba yang dihasilkan deitambah dengan akumulasi depresiasi selalu lebih besar dari nilai laba yang dihasilkan ditambah dengan akumulasi depresiasi selalu lebih besar dari nilai arus kas untuk kegiatan operasi. Nilai arus kas untuk kegiatan operasi sering kali bernilai negatif yang diakibatkan oleh tingginya pembayaran yang dilakukan untuk pemasok dan kontraktor. Perusahaan property dan real estate, biasanya memiliki pembayaran yang tinggi kepada pemasok dan kontraktor, karena perusahaan banyak melakukan pembangunan untuk perumahan, gedung, pusat perbelanjaan dan lain-lain sebagai persediaan bagi perusahaan, sedangkan pemasukan arus kas dari kegiatan operasi biasanya berasal dari pembayaran dari 
pelanggan. Pelanggan biasanya tidak akan langsung membayar lunas dengan uang tunai, biasanya pembayaran hanya berupa uang muka dan seterusnya akan membayar secara kredit kepada perusahaan. Sehingga pendapatan yang diakui lebih besar jika dibandingkan dengan penerimaan berupa kas, karena perusahaan menggunakan pencatatan dengan metode akrual atau mengakui pendapatan dan beban pada saat terjadinya transaksi tersebut.

\section{Pemilihan Metode Regresi Data Panel. Uji Fixed Effect (Uji Chow)}

Tabel 2. Hasil Uji Chow

Redundant Fixed Effects Tests

Pool: INTEGRITAS

Test cross-section fixed effects

\begin{tabular}{lrrr}
\hline \hline Effects Test & Statistic & d.f. & Prob. \\
\hline \hline Cross-section F & 7.163032 & $(16,150)$ & 0.0000 \\
Cross-section Chi-square & 96.4944738 & 16 & 0.0000 \\
\hline \hline
\end{tabular}

Berdasarkan Tabel 2, diperoleh nilai Probability (p-value) cross section F sebesar 0.0000 atau lebih kecil dari taraf signifikasi 5\%. Oleh karena itu, berdasarkan ketentuan pengambilan keputusan maka hipotesis $\mathbf{H}_{\mathbf{0}}$ ditolak, sehingga model yang digunakan adalah fixed effect. Karena model yang terpilih adalah fixed effect, maka uji selanjutnya adalah uji hausman.

\section{Uji Random Effect (Uji Hausman)}

Tabel 3. Hasil Uji Hausman

Correlated Random Effects - Hausman Test

Pool: INTEGRITAS

Test cross-section random effects

\begin{tabular}{lrrr}
\hline \hline Test Summary & $\begin{array}{l}\text { Chi-Sq. } \\
\text { Statistic }\end{array}$ & Chi-Sq. d.f. & Prob. \\
\hline \hline Cross-section random & 2.248246 & 3 & 0.5225 \\
\hline \hline
\end{tabular}

Berdasarkan Tabel diatas, hasil uji Hausman menunjukkan bahwa Random Effect Model (REM) sebaiknya digunakan dalam regresi data panel penelitian ini dengan nilai statistik Hausman sebesar 0.5225 > dari nilai signifikansi 5\%.

Uji Simultan (Uji F). Berdasarkan Tabel 4 dapat dilihat bahwa nilai prob (F-static) adalah sebesar 0.013277 atau lebih kecil dari 5\%, maka $\mathbf{H}_{0}$ ditolak, berarti bahwa variabel independen dalam penelitian ini, yaitu komisaris independen, komite audit, dan financial distress secara simultan atau bersama-sama berpengaruh terhadap variabel dependen yaitu integritas laporan keuangan pada perusahaan sektor property dan real estate periode 2005- 
2014 sebesar 6,2\% sedangkan sisanya 93,8\% dipengaruhi oleh variabel lain diluar penelitian.

Tabel 4. Hasil Uji Simultan (Uji F)

\begin{tabular}{lllr} 
R-squared & 0.062415 & Mean dependent var & 159.3753 \\
Adjusted R-squared & 0.045471 & S.D. dependent var & 611.6928 \\
S.E. of regression & 597623.9 & Sum squared resid & 59287621 \\
F-statistic & 3.683548 & Durbin-Watson stat & 1.061508 \\
Prob(F-statistic) & 0.013277 & & \\
\hline \hline
\end{tabular}

\section{Uji Parsial (Uji t)}

Tabel 5. Hasil Uji Parsial

\begin{tabular}{|c|c|c|c|c|}
\hline \multicolumn{5}{|c|}{$\begin{array}{l}\text { Dependent Variable: CONACC? } \\
\text { Method: Pooled EGLS (Cross-section random effects) } \\
\text { Date: } 02 / 07 / 16 \text { Time: } 21: 15 \\
\text { Sample: } 20052014 \\
\text { Included observations: } 10 \\
\text { Cross-sections included: } 17 \\
\text { Total pool (balanced) observations: } 170 \\
\text { Swamy and Arora estimator of component variances }\end{array}$} \\
\hline Variable & Coefficient & Std. Error & t-Statistic & Prob. \\
\hline C & -1471.334 & 1974.352 & -0.745224 & 0.4572 \\
\hline KOMIN? & 1679.517 & 605.8331 & 2.772243 & 0.0062 \\
\hline KOMAU? & 370.3452 & 638.9885 & 0.579580 & 0.5630 \\
\hline FINDIS? & 18.44889 & 9.714342 & 1.899140 & 0.0593 \\
\hline
\end{tabular}

Berdasarkan hasil pengujian diatas dapat diketahui bahwa persamaan regresi data panel adalah sebagai berikut:

\section{CONACC $=-1471,334+1679,517$ KOMIN + 370,3452KOMAU + 18,44889FINDIS}

Persamaan diatas dapat diartikan bahwa: (1) Koefisien intersep sebesar -1471,334 yang berarti apabila variabel Komisaris Indpenden, Komite Audit dan Financial Distress konstan, maka tingkat integritas laporan keuangan perusahaan Property dan Real Estate akan turun sebesar -1471,334. (2) Koefisien Komisaris Independen sebesar 1679,517 yang berarti jika terjadi peningkatan Komisaris Independen sebesar 1 satuan dan variabel lainnya konstan, maka integritas laporan keuangan akan mengalami peningkatan sebesar 1679,517 satuan. (3) Koefisien Komite Audit sebesar 370,3452 yang berarti jika terjadi peningkatan Komite Audit sebesar 1 satuan dan variabel lainnya konstan, maka integritas laporan keuangan akan mengalami peningkatan sebesar 370,3452 satuan. (4) Koefisien Financial Distress sebesar 18,44889 yang berarti jika terjadi peningkatan Financial Distress sebesar 1 satuan dan variabel lainnya konstan, maka integritas laporan keuangan akan mengalami peningkatan sebesar 18,44889 satuan. 
Berdasarkan hasil uji metode Random Effect model dapat disimpulkan bahwa: Pertama. Berdasarkan hasil pengujian yang telah dilakukan, komisaris independen memiliki nilai prob $0.0062<0.05$, maka $\mathbf{H}_{\mathbf{0}}$ ditolak yang berarti variabel komisaris independen memiliki pengaruh secara parsial terhadap variabel integritas laporan keuangan. Selanjutnya, dapat dilihat bahwa komisaris independen memiliki nilai koefisien kearah positif sebesar 1679,517 yang menunjukkan hubungan secara positif, dimana semakin banyak jumlah komisaris independen maka akan semakin tinggi tingkat integritasnya. Hal ini sesuai dengan hipotesis yang dibangun oleh penulis yang menyatakan bahwa semakin banyak komisaris independen maka semakin tinggi tingkat integritas laporan keuangannya. Hal ini sehubungan dengan Peraturan Otoritas Jasa Keuangan No. 33/POJK.04/2014 tentang Direksi dan Dewan Komisaris Emiten atau Perusahaan Publik yang menyatakan bahwa tugas komisaris independen adalah melakukan pengawasan dan bertanggung jawab atas pengawasan terhadap kebijakan pengurusan, jalannya pengurusan pada umumnya, baik mengenai Emiten atau Perusahaan Publik maupun usaha Emiten atau Perusahaan Publik, dan memberi nasihat kepada Direksi. Sehingga, dengan adanya komisaris independen dalam suatu perusahaan maka integritas laporan keuangannya akan meningkat, karena telah ada badan pengawas yang mengawasi pembuatan laporan keuangan tersebut yang dilakukan oleh pihak manajemen agar tidak merugikan atau menyesatkan pengguna laporan keuangan tersebut. Hal ini didukung dengan penelitian yang dilakukan oleh Nicolin dan Sabeni (2013) dan Saksakotama (2014).

Kedua. Berdasarkan hasil pengujian yang telah dilakukan, variabel komite audit memiliki nilai prob $0.5630>0.05$, maka $\mathbf{H}_{0}$ diterima yang berarti variabel komite audit tidak memiliki pengaruh secara parsial terhadap variabel integritas laporan keuangan. Persamaan regresi yang terdapat pada Tabel 5 memperlihatkan koefisien dari komite audit sebesar 370,3452 ini menunjukkan jika komite audit mengalami kenaikan 1 kali, maka akan terjadi kenaikan inegritas laporan keuangan sebesar 370,3452 kali dan sebaliknya jika komite audit mengalami penurunan maka integritas laporan keuangan juga akan mengalami penurunan. Hal ini bertentangan dengan hipotesis yang dibangun oleh penulis yang menyatakan bahwa semakin banyak jumlah komite audit, maka akan semakin tinggi integritas laporan keuangnnya. Hal ini bisa terjadi karena keberadaan komite audit kurang dapat memfasilitasi komunikasi antar pembuat laporan keuangan dan memastikan terpenuhinya standar, atau dengan kata lain, fungsi komite audit sebagai pengawas dan penelaah laporan keuangan serta sebagai fasilitator dalam mengkomunikasikan hal-hal yang berhubungan dengan audit kepada dewan direksi tidak berjalan dengan seharusnya. Sehingga, komite audit kurang mampu dalam mengurangi kecurangan terhadap pelaporan keuangan dan meningkatkan integritas laporan keuangan. Hal ini didukung penelitian yang dilakukan oleh Hardiningsih (2010) dan Saksakotama (2014) .yang menyatakan bahwa komite audit tidak berpengaruh terhadap integritas laporan keuangan.

Ketiga. Variabel financial distressmemiliki nilai prob $0.0593>0.05$, maka $\mathbf{H}_{\mathbf{0}}$ diterima yang berarti variabel financial distress tidak memiliki pengaruh secara parsial terhadap variabel integritas laporan keuangan periode 2005-2014. Persamaan regresi yang terdapat pada Tabel 5 memperlihatkan koefisien dari variabel financial distress sebesar 18,44889 yang menunjukkan jika financial distress mengalami kenaikan sebesar 1 kali maka akan terjadi kenaikan integritas laporan keuangan sebesar 18,44889 kali, dan sebaliknya jika financial distress menurun, maka variabel integritas laporan keuangan juga akan menurun. Hal ini bertentangan dengan hipotesis yang telah dibangun oleh penulis yang menyatakan bahwa semakin tinggi nilai financial distress, maka akan semakin 
menurun tingkat integritas laporan keuangannya. Hal ini dapat terjadi karena dalam PSAK No. 1 (2014) telah disebutkan bahwa karakteristik kualitatif dalam laporan keuangan salah satunya adalah andal dan relevan. Laporan keuangan yang baik akan selalu menerapkan hal tersebut agar laporan keuangannya dapat digunakan oleh pengguna laporan keuangan. Hal ini lah yang menyebabkan meskipun perusahaan sedang mengalami masa financial distress atau kesulitan keuangan tidak akan mempengaruhi tingkat integritas dari laporan keuangan tersebut. Laporan keuangan harus tetap disajikan secara andal, relevan, dapat dipahami dan dapat dibandingkan. Hal ini sesuai dengan penelitian yang dilakukan oleh Alhayati (2013) yang menyatakan bahwa financial distress tidak memiliki pengaruh terhadap konservatisme akuntansi, dalam penelitian ini variabel integritas laporan keuangan diproksi dengan konservatisme akuntansi.

\section{PENUTUP}

Simpulan. Berdasarkan analisis regresi data panel, menunjukkan bahwa Komisaris Independen, Komite Audit, dan Financial Distress berpengaruh secara simultan terhadap integritas laporan keuangan. Secara parsial hanya variabel komisaris independen yang memiliki pengaruh dengan arah positif terhadap integritas laporan keuangan. Sedangkan Komite Audit dan financial distress tidak berpengaruh terhadap integritas laporan keunagan.

Saran. Bagi penelitian selanjutnya disarankan untuk menambah variabel independen yang diprediksi dapat mempengaruhi integritas laporan keuangan, seperti independensi dan kualitas auditor atau mekanisme good corporate governance. Bagi investor agar mengumpulkan informasi tentang perusahaan yang menjadi tempat investasi agar meminimalisasikan resiko dan mengoptimalkan keuntungan. Bagi manajemen disarankan untuk menunjuk komisaris independen dan komite audit yang berintegritas tinggi dan perusahaan agar mengenali tanda-tanda awal kebangkrutan dan segera mengantisipasi kemungkinan tersebut.

\section{DAFTAR RUJUKAN}

Aljufri. (2014) "Dampak Audit Quality dan Corporate Governance terhadap Integritas Laporan Keuangan”. Jurnal Ilmiah Ekonomi dan Bisnis, 11 (2): 267-280. ISSN: $1829-9822$.

Alhayati, Fajri. (2013) "Pengaruh Tingkat Hutang (Leverage) dan Tingkat Kesulitan Keuangan Perusahaan Terhadap Konservatisme Akuntansi”. Jurnal Universitas Negeri Padang.

Altman, Edward I dan Edith. H. (2006) Corporate Financial Distress and Bankruptcy (3rd Edition). USA: Wiley Finance.

Arikunto, Suharsimi. (2010) Prosedur Penelitian Suatu Pendekatan Praktik (Ed. Revisi 2010). Jakarta: Rineka Cipta.

Beams, Joseph dan Yun. C.Y. (2015) "The Effect of Financial on Auditor Conservatism:US Evidence”. Accounting Research Journal, 28 (2): 160-171. ISSN: 1090-9616. 
Boynton, William C. dan Raymond N. J. (2006) Modern Auditing (8th Edition). US: Wiley.

Dewi, Ni Kd. S.L, dan I Ketut. S. (2014) "Pengaruh Struktur Kepemilikan Manajerial, Leverage, dan Finacial Distress terhadap Konservatisme Akuntansi”. E-Jurnal Akuntansi Universitas Udayana. ISSN: 2302-8556.

Fathurahmi, Afina, Edi. S, dan Sri. F. (2015) Pengaruh Growth Opportunities dan Financial Distress terhadap Conservatism Accounting pada Perusahaan Textile dan Garment yang Terdaftar di Bursa Efek Indonesia Periode 2010-2014. Prosiding Penelitian Sivitas Akademika Unisba (Sosial dan Humaniora), Gelombang 2.

Foroghi, Dariush, Hadi A, dan Zahra, N.F. (2013) "Corporate Governance and Conservatism". International Journal of Academic Research in Accounting, Finance, Management Science, 3 (4): 61-71. E-ISSN: 2225-8329.

Ghozali, Imam. (2011) Aplikasi Analisis Multivariate dengan Program IBM SPSS 20. Semarang: Badan Penerbit Universitas Diponegoro.

Givoly, Dan dan Carla H. (2000) "Rising Conservatism: Implication for Financial Analysis”. Financial Analists Journal, 56-74.

Hadi, Syamsul., dan Anggraeni, Atika. (2008) "Pemilihan Prediktor Delisting Terbaik (Perbandingan Antara The Zmijewski Model, The Altman Model dan The Springate Model). Universitas Islam Indonesia”: journal.uii.ac.id, 12, (2): 178-192

Hardiningsih, Pancawati. (2010) "Pengaruh Independensi, Corporate Governance, dan Kualitas Audit terhadap Integritas Laporan Keuangan”. Kajian Akuntansi, 2 (1): 6176. ISSN: 1979-4886.

Haron, Hasnah, Bambang H., Mahfooz A., dan Ishak I. (2009) "Factors Influencing Auditors Going Concern Opinion”. Asian Academy of Management Journal, 14. (1): $1-19$.

Hendriksen, Eldon. S dan Michael F.V.B. (2014) Teori Akuntansi Buku 1 (Edisi 5). Tangerang: Interaksara.

Ikatan Akuntan Indonesia. (2014) Standar Akuntansi Keuangan Per 1 Juli 2013. Jakarta: IAI.

Juanda, Bambang \& Junaidi. (2012) Ekonometrika Deret Waktu. Bogor: IPB Dress.

Keputusan Ketua Badan Pengawas Pasar Modal dan Lembaga Keuangan No. KEP643/BL/2012 tentang Pembentukan dan Pedoman Pelaksanaan Kerja Komite Audit.

Keputusan Menteri BUMN No. KEP-117/M-MBU/2002 tentang Penerapan Praktik Corporate Governance pada Badan Usaha Milik Negara (BUMN).

Kootanaee, Akbar Javadian, Jalal. S, Morteza. N, dan Milad. J. K. (2013) “Accounting Conservatism and Corporate Governance Mechanism: Evidence from Tehran Stock Exchange”. International Journal of Economics, Business and Finance, 1 (10): 301319. ISSN: 2327-8188.

Munif, Naila. R dan Tarmizi. A. (2013) "Analisis Pengaruh Komite Audit terhadap Hubungan Antara Rotasi Audit dan Audit Tenure dengan Konservatisme". Diponegoro Journal of Accounting, 2 (3): 1-12. ISSN: 2337-3806.

Nicolin, Octavia dan Arifin Sabeni. (2013) "Pengaruh Struktur Corporate Governance, Audit Tenure, dan Spesialisasi Industri Auditor terhadap Integritas Laporan Keuangan”. Diponegoro Journal of Accounting, 2 (3): 1-12. ISSN: 2337-3806.

Nugroho, Deffa A. dan Siti M. (2012) "Pengaruh Struktur Kepemilikan Manajerial, Debt Convenant, Tingkat Kesulitan Keuangan Perusahaan, dan Risiko Litigasi terhadap Konservatisme Akuntansi”. Diponegoro Journal of Accounting, 1 (1): 1-13. 
Noviantari, Ni Wayan, dan Ni Made Dwi. R. (2015) "Pengaruh Financial Distress, Ukuran Perusahaan, dan Laverage Pada Konservatisme Akuntansi”. E-Jurnal Akuntansi, Universitas Udayana, ISSN: 2302-8556.

Okpala, Kenneth Enoch. (2012) “Auditee Comittee and Integrity of Financial Statements: A Preventive Mechanism for Corporate Failure”. Australian Journal of Business and Managements Research, 2 (08): 32-40. ISSN: 1839-0846.

Peraturan Menteri Dalam Negeri No. 3 Tahun 1987 tentang Penyediaan dan Pemberian Hak Atas Tanah untuk Keperluan Perusahaan Pembanguna.

Peraturan Menteri Dalam Negeri No. 5 Tahun 1974 tentang Ketentuan-ketentuan Mengenai Penyediaan dan Pemberian Tanah untuk Keperluan Perusahaan.

Peraturan Otoritas Jasa Keuangan No. 33/POJK.04/2014 tentang Direksi dan Dewan Komisaris Emiten atau Perusahaan Publik

Pramudita, Nathania. (2012). Pengaruh Tingkat Kesulitan Keuangan dan Tingkat Hutang terhadap Konservatisme Akuntansi pada Perusahaan Manufaktur di BEI. Jurnal Ilmiah Mahasiswa Akuntansi, Vol 1 No. 2.

Putra, Daniel. S.T., dan Dul Muid. (2012) "Pengaruh Independensi, Mekanisme Corporate Governance, Kualitas Audit, dan Manajemen Laba terhadap Integritas Laporan Keuangan”. Diponegoro Journal of Accounting, 1 (2).

Risdiyani, Fani dan Kusmuriyanto. (2015) "Analisis Faktor-Faktor yang Mempengaruhi Penerapan Konservatisme Akuntansi”. Accounting Analysis Journal 4 (3). ISSN: 2252-6765.

Rosadi, Dedi. (2012) Ekonometrika dan Analisis Runtun Waktu Terapan dengan Eviews. Yogyakarta: Andi.

Saksakotama, Paramita. H, dan Nur Cahyonowati. (2014) "Determinan Integritas Laporan Keuangan Perusahaan Manufaktur di Indonesia”. Diponegoro Journal of Accounting, 3 (2): 1-13. ISSN: 2337-3806.

Schmuck, Martin. (2013) Financial Distress and Corporate Turnaround. Munchen: Springer Gabler.

Sekaran, Uma \& Bougie, Roger. (2013) Research Methods for Business, A Skill Building Approach. United Kingdom: Wiley \& Sons.

Sjahrial, Dermawan. (2010) Manajemen Keuangan (Edisi 4th). Jakarta: Mitra Wacana Media.

Smith, Malcolm. Ren, Yun. Dong, Yinan. (2011) “The Predictive Ability of Conservatism and Governance Variables in Corporate Financial Disclosure”. Asian Review of Accounting, 19 (2): 171-185.

Subramanyam, K.R dan John J. Wild. (2010) Analisis Laporan Keuangan (Edisi 10). Jakarta: Salemba Empat.

Sugiyono. (2013) Metode Penelitian Kuantitatif, Kualitatif, dan R\&D. Bandung: Alfabeta.

Surat Keputusan Menteri Perumahan Rakyat No. 05/KPTS/BKP4N/1995 tentang Tata Laksana Pendaftaran Dalam Pembinaan Badan Usaha dan Jasa Profesional di Bidang Pembangunan Perumahan dan Permukiman.

Suwardjono. (2010) Teori Akuntansi Perekayasaan Pelaporan Keuangan (Edisi Ketiga). Yogyakarta: BPFE-Yogyakarta.

Van Horne, James C dan John M. W, Jr. (2012) Prinsip-Prinsip Manajemen Keuangan (Edisi 13). Jakarta: Erlangga. 
Wulandari, Yani N.P dan I Ketut Budiartha. (2014) “Pengaruh Struktur Kepemilikan, Komite Audit, Komisaris Independen dan Dewan Direksi terhadap Integritas Laporan Keuangan”. E-Jurnal Akuntansi Universitas Udayana, ISSN: 2302-8556.

Yunos, Rahimah. M, Syahrul. A.A, Normala. S. (2014) "The Influence of Internal Governance Mechanism on Accounting Conservatism. International Conference on Accounting Studies”, Procidia Social and Behavioral Sciences, 501-507. 